\title{
Profiles of Persistent Organochlorine Pollutants (POPs) in Tissues of Marketable Common Carp and in Bottom Sediments of Selected Ponds of South and West Bohemia
}

\author{
Z. SVOBODOVÁ ${ }^{1,2}$, V. ŽLÁBEK ${ }^{1,3}$, T. RANDÁK ${ }^{1}$, J. MÁCHOVÁ ${ }^{1}$, J. KOLÁŘOVÁ ${ }^{1}$, \\ J. HAJŠLOVÁ ${ }^{4}$, P. SUCHAN ${ }^{4}$ \\ ${ }^{1}$ University of South Bohemia České Budějovice, \\ Research Institute of Fish Culture and Hydrobiology, Vodňany, Czech Republic \\ ${ }^{2}$ University of Veterinary and Pharmaceutical Sciences, Brno, Czech Republic \\ ${ }^{3}$ University of South Bohemia, Faculty of Agriculture, České Budějovice, Czech Republic \\ ${ }^{4}$ Institute of Chemical Technology, Dept. of Food Chemistry and Analysis, Prague, Czech Republic
}

Received November 15, 2002

Accepted March 25, 2003

\begin{abstract}
Svobodová Z., V. Žlábek, T. Randák, J. Máchová, J. Kolářová, J. Hajšlová, P. Suchan: Profiles of Persistent Organochlorine Pollutants (POPs) in Tissues of Marketable Common Carp and in Bottom Sediments of Selected Ponds of South and West Bohemia. Acta Vet. Brno 2003, 72: 295-309.

The aim of the study was to evaluate the state of selected ponds in South and West Bohemia from the point of view of selected POPs contamination (DDT and its metabolites, $\mathrm{HCH}$ - isomers, HCB and OCS). Six ponds were sampled during autumn periods of 1999-2001. Bottom sediment samples were taken from every pond, as well as muscle, liver and gonad samples from 5 to 7 specimens of marketable common carp per pond. The DDT and its metabolites were determined in fish muscle (w.w. - wet weight) in range of 7.91 to $86.48 \mu \mathrm{g} \cdot \mathrm{kg}^{-1}$, sum of $\mathrm{HCH}$ isomers in range of 0.20 to $6.33 \mu \mathrm{g} \cdot \mathrm{kg}^{-1}, \mathrm{HCB}$ in range of 0.31 to $6.17 \mu \mathrm{g} \cdot \mathrm{kg}^{-1}$ and OCS in range of 0.02 to $0.80 \mu \mathrm{g} \cdot \mathrm{kg}^{-1}$.

The results demostrated comparable indicative ability of fish tissues and bottom sediments for evaluation of pond load by the monitored POPs. Correlation coefficients between their contents in sediments and in fish muscle were as followed: $r=0.927$ for the sum of DDT and its metabolites; $r=0.780$ for $\mathrm{HCH}$ isomers; $r=0.979$ for $\mathrm{HCB} ; \mathrm{r}=0.481$ for OCS. The rates of pond load referred to the intensity of agricultural and industrial production in their drainage areas. A close correlation $(\mathrm{r}=0,810-0,999)$ was also found between the content of DDT, HCH, HCB and fat in individual tissues of carp from pond. Any value measured for the POPs under study did not exceed the maximum limit of residues as defined by legislation in force.

The study contributed to quality evaluation of carp as the main representative of marketable fish in the Czech Republic, as well as to evaluation of its environment. Thus the study assisted to the strategy of food safety.
\end{abstract}

Cyprinus carpio L., DDT and its metabolites, HCH isomers, HCB, OCS, muscle, liver, gonads

Problems of hygienic and toxicological quality of food became a recent priority of the European Union. Before accessing the EU, Czech Republic now exerts a big effort to follow the world trend in development of food hygiene. This effort is directed towards the strategy of food safety. Since the ecosystems of surface waters become a final recipient of most foreign substances originating from anthropogenic activity, research and control are focused to hygiene of freshwater fish production.

Carp with its 87-90\% of total production is the main fish species in the Czech Republic both for the local market and for export (Vách a 1998; V os tradovský 2002). Fulfilling the strategy of food safety, attention must be paid to the control of this fish species, as well as to the environment where it is grown. Above all, the effort should be focused to large ponds decisive for marketable carp production. This effort should be further focused to ponds that concentrated and treated (or still concentrate and treat) various 
types of waste waters, above all the municipal ones but also those from food processing industry and others.

This study is focused on selected persistent organic pollutants (POPs), namely to organochlorine POPs represented by DDT and its metabolites, $\mathrm{HCH}$ isomers, hexachlorbenzene (HCB) and octachlorstyrene (OCS).

The DDT-based pesticides were one of the most efficient insecticide preparations, succesfully used in large-scale in agriculture, forestry and civic hygiene. Nevertheless, the problems associated with application of DDT began to appear as soon as at the end of 1940's. Many insect species became resistant to this insecticide. Cars on (1962) warned about the risk of DDT persistence in the environment and about its ability of accumulation in the lipidic component of biota. Damage of fish and other wild animals were proven after penetration of this insecticide into their food webs. High acute toxicity of DDT-based preparations was documented by Mertlík and S vobodová (1973), John son and Finley (1980), Lakota et al. (1983). Recently, DDT and its metabolites (DDE in particular) were classified as highly suspicious endocrine disruptors (Kavlock et al. 1996; Keith 1997; You 2000). The DDE, together with PCBs are the major ubiquitous environmental pollutants. These two compounds represent a significant risk to wildlife and human health (B ergman et al. 2002; Gupta and Robertson 2002). Moreover, the persistence of DDE in the environment and its xenoestrogenic effects are important impulses for further monitoring and control of these compounds. Heseltine (2001) also dealt with the effects of DDT in food and in environment.

The use of lindane (gamma-isomer of $\mathrm{HCH}$ ) as an insecticide was introduced in 1940's. It was also applied as a fungicide and antiparasitic agent. The technical lindane was accompanied by 5 other isomers, particularly with alpha and beta isomers. With expanded application, its negative characteristics occurred, namely persistence in the environment (Duffu s 1980), food web contamination (Kinloch et al. 1992) and high toxicity for fish (Johnson and Finley 1980). US EPA banned the application of lindane as a potential cancerogenic agent. Since $\mathrm{HCH}$ is a highly volatile substance (up to $99 \%$ may pass into the atmosphere) (Clark 1992) more soluble in water contrary to other organic pollutants (Norstrom and Muir 1997). Its presence is recorded mainly in freshwater and marine ecosystems. The $\mathrm{HCH}$ volatility and vapour tension declines with decreasing temperatures. This results in its accumulation mainly in arctic ecosystems (Iw at a et al. 1993). Alpha- and beta-HCH are noted to be universal environmental contaminants, with concentrations detected in samples of air, rain water, fresh water, sea water, soil, sediment, and numerous plant and animal species, as well as in several important food items. A review of studies on environmental and metabolic fate concludes that alpha- and beta- $\mathrm{HCH}$, when compared with lindane, are characterized by a higher bioconcentration in the environment, a slower rate of biodegradation by ultraviolet light, and a slower rate of elimination from organisms (Saunders and Harper 1994).

Hexachlorbenzene (HCB) was utilised in agriculture as a fungicide for treatment of cereal seed stock and in chemistry, mainly in production of synthetic rubber, ammunition etc. Alike the chlorinated organic compounds mentioned above, HCB is highly persistent in the natural environment and also possesses high bioaccumulation ability, resulting in contamination of food webs (Augustijn-Beckers et al. 1994).

US EPA defines octachlorinestyrene (OCS) as a priority persistent toxic pollutant with high potential of bioaccumulation. Industrial production and almost all the chemistry is a source of OCS for the environment. A range of recent studies is devoted to the problems of OCS accumulation and distribution in aquatic ecosystems (Kaminsky and Hites 1984; Jorgensen et al. 1997; Bester et al. 1998).

Systematic monitoring of the occurrence of persistent organic pollutants (POPs), 
particularly of DDT and its metabolites, $\mathrm{HCH}$ and HCB isomers in the Czech Republic was commenced at the end of 1970's. Attention was paid to the level of load of the Berounka river catchment area (S vobodová et al. 1983a). Monitoring was further extended to fish from a range of farm ponds (Svobodová et al.1983b, 1995), to rainbow trout from intensive culture (Svobodová et al. 1996), to predatory and non-predatory fish from reservoirs (Kredl et al. 1989; Hajšlová et al. 1997), and above all to fish from the Elbe river and from its major tributaries (Svobodová et al. 1993a, 1993b, 1994). The results signalized increased load of fish from running waters by chlorinated pesticides (DDT and its metabolites, $\mathrm{HCH}$ isomers), particularly species with higher fat content (chub, wels, eel) and species ethologically associated with river bottom (barbel). The results of analyses confirmed the worldwide trend of reduction in primary DDT content and prevailing occurrence of DDE metabolite.

The aims of the study were:

- to continue the already started systematic monitoring the level of contamination with selected persistent organic pollutants (POPs) contamination in aquatic environment localities in the Czech Republic

- to compare the situation in contamination with selected POPs in six important production ponds in the area of South and West Bohemia, based on results of analyses of marketable carp tissues and bottom sediments

- to describe the distribution of monitored POPs in individual tissues of marketable carp

- to contribute to the evaluation of food safety of carp as the main fish species.

\section{Materials and Methods}

Monitoring of the content of selected POPs (DDT and its metabolites, HCH isomers, hexachlorbenzene - HCB, octachlorinestyrene - OCS) in tissues of marketable carp (Cyprinus carpio L.) and in bottom sediments were performed in autumns of 1999, 2000 and 2001 during harvests of the following ponds (Fig. 1):

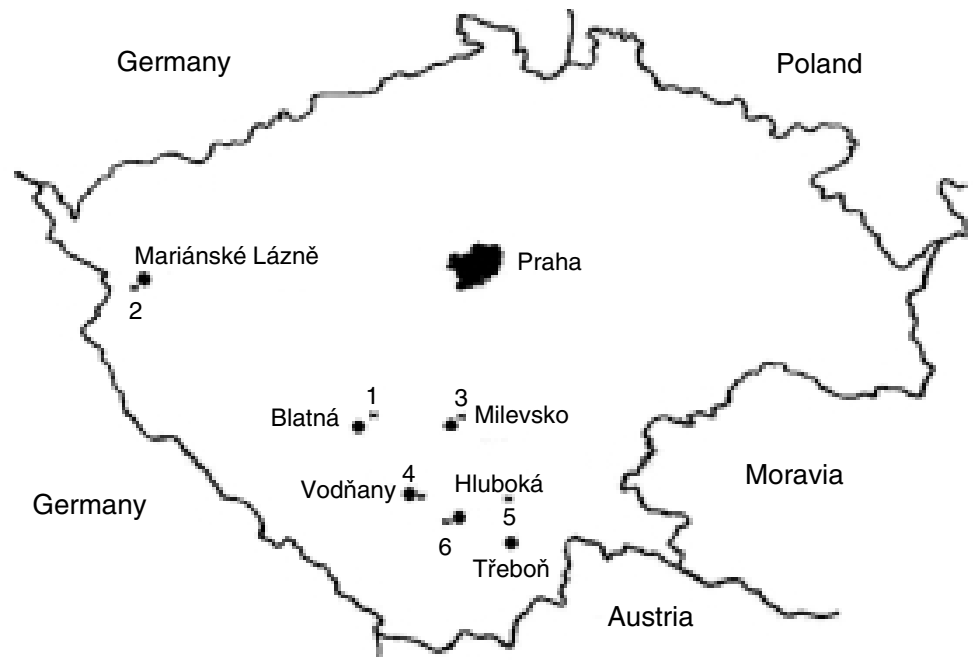

Fig. 1. Map of ponds under study in the region of South and West Bohemia (1-Buzický, 2 - Regent, 3-Tovaryš, 4-Dřemliny, 5-Horusický, 6-Bezdrev)

Buzický (55 ha) owned by the Blatenská ryba s.r.o. It is situated in cadastres of Blatna town and Mrakov village. Buzický is a biological pond serving final treatment of water from the water treatment plant of the Blatna town. It is also supplied from the Mračovský brook and the Lomnice river with a large catchment area with an intensive agriculture production. Buzický pond is a semi-intensive pond with one-season way of management. The main cultured fish species are carp ( 85 tons harvest production), tench and minor predatory and herbivorous fish. 
Table 1

Contents of DDT and its metabolites in tissues $\left(\mu \mathrm{g} \cdot \mathrm{kg}^{-1}\right.$ w.w.) of marketable carp

\begin{tabular}{|c|c|c|c|c|c|c|c|c|c|c|c|}
\hline Pond Tissue & & $\mathrm{n}$ & Body mass in $\mathrm{g}$ & Fat $(\%)$ & o,p-DDE & p,p-DDE & o,p-DDD & p,p-DDD & o,p-DDT & p,p-DDT & $\sum$ DDT \\
\hline \multicolumn{12}{|l|}{ Buzický } \\
\hline \multirow[t]{2}{*}{ Muscle } & mean & \multirow{2}{*}{5} & 2164 & 7.54 & 0.99 & 53.15 & 2.16 & 12.94 & 0.36 & 1.38 & 70.98 \\
\hline & $\mathrm{SD}$ & & 261.2 & 2.58 & 0.43 & 8.74 & 0.48 & 2.57 & 0.27 & 0.33 & 11.93 \\
\hline Liver* & mean & 5 & 2164 & 15.79 & 2.05 & 94.76 & 7.26 & 18.79 & 0.32 & 2.05 & 125.23 \\
\hline Ovaries* & female & 3 & 2210 & 8.62 & 0.34 & 52.47 & 2.15 & 13.53 & 0.26 & 1.21 & 69.96 \\
\hline Testes* & male & 2 & 2090 & 1.12 & 0.20 & 10.57 & 0.63 & 2.54 & 0.26 & 0.60 & 14.66 \\
\hline \multicolumn{12}{|l|}{ Regent } \\
\hline \multirow[t]{2}{*}{ Muscle } & mean & \multirow{2}{*}{6} & 3157 & 10.70 & 1.10 & 3.93 & 0.96 & 10.11 & 0.24 & 0.40 & 16.74 \\
\hline & SD & & 408.7 & 4.07 & 0.47 & 3.15 & 0.53 & 6.30 & 0.30 & 0.18 & 7.71 \\
\hline \multirow{2}{*}{ Liver } & mean & \multirow{2}{*}{7} & 3236 & 11.63 & 4.24 & 11.64 & 4.02 & 11.43 & 5.60 & 1.58 & 38.51 \\
\hline & $\mathrm{SD}$ & & 427.7 & 6.22 & 2.65 & 6.50 & 2.20 & 8.08 & 4.42 & 0.72 & 16.06 \\
\hline Kidney* & mean & 7 & 3236 & 6.11 & 0.43 & 3.18 & 1.59 & 5.80 & 0.12 & 0.55 & 11.67 \\
\hline \multirow[t]{2}{*}{ Ovaries } & mean & \multirow{2}{*}{4} & 3239 & 6.00 & 0.74 & 5.01 & 1.93 & 7.12 & 0.55 & 1.74 & 17.09 \\
\hline & SD & & 587.5 & 3.77 & 0.33 & 3.39 & 1.46 & 6.21 & 0.64 & 2.35 & 12.00 \\
\hline \multirow[t]{2}{*}{ Testes } & mean & \multirow{2}{*}{3} & 3232 & 2.93 & 0.74 & 3.42 & 1.26 & 6.03 & 0.30 & 0.19 & 11.94 \\
\hline & $\mathrm{SD}$ & & 176.2 & 1.44 & 0.37 & 2.15 & 0.85 & 3.86 & 0.26 & 0.08 & 7.37 \\
\hline \multicolumn{12}{|l|}{ Tovaryš } \\
\hline \multirow[t]{2}{*}{ Muscle } & mean & \multirow{2}{*}{7} & 1689 & 4.26 & 0.60 & 52.52 & 6.30 & 24.97 & 0.58 & 1.50 & 86.48 \\
\hline & SD & & 181.1 & 1.47 & 0.28 & 16.56 & 2.70 & 8.72 & 0.23 & 0.51 & 28.40 \\
\hline \multirow[t]{2}{*}{ Liver* } & female & 4 & 1673 & 9.73 & 1.23 & 123.97 & 14.65 & 57.01 & 1.03 & 1.89 & 199.78 \\
\hline & male & 3 & 1710 & 13.34 & 1.99 & 173.47 & 22.46 & 87.53 & 2.08 & 4.46 & 292.00 \\
\hline Testes* & male & 3 & 1710 & 2.37 & 0.30 & 26.99 & 3.45 & 11.95 & 0.25 & 0.70 & 43.63 \\
\hline \multicolumn{12}{|c|}{ Dřemliny } \\
\hline \multirow[t]{2}{*}{ Muscle } & mean & \multirow{2}{*}{7} & 1980 & 5.10 & 0.13 & 12.97 & 1.07 & 3.81 & 0.13 & 1.40 & 19.51 \\
\hline & SD & & 276.5 & 1.58 & 0.05 & 3.75 & 0.32 & 1.08 & 0.07 & 0.75 & 5.55 \\
\hline \multirow[t]{2}{*}{ Liver* } & female & 3 & 1775 & 4.09 & 0.10 & 7.84 & 0.90 & 2.46 & 0.08 & 0.69 & 12.08 \\
\hline & male & 4 & 2134 & 3.11 & 0.11 & 7.62 & 0.59 & 2.23 & 0.07 & 0.49 & 11.09 \\
\hline Ovaries* & female & 3 & 1775 & 4.15 & 0.08 & 6.76 & 0.49 & 2.16 & 0.08 & 1.17 & 10.75 \\
\hline Testes* & male & 4 & 2134 & 0.67 & 0.02 & 2.07 & 0.12 & 0.56 & 0.01 & 0.17 & 2.95 \\
\hline \multicolumn{12}{|c|}{ Horusický } \\
\hline Muscle & mean & 7 & 2190 & 4.39 & 0.07 & 3.63 & 0.94 & 3.16 & 0.03 & 0.08 & 7.91 \\
\hline & SD & 1 & 166.8 & 1.68 & 0.02 & 1.00 & 0.32 & 0.97 & 0.02 & 0.02 & 2.27 \\
\hline Liver* & female & 2 & 2355 & 9.92 & 0.17 & 10.65 & 2.81 & 8.67 & 0.02 & 0.20 & 22.53 \\
\hline & male & 5 & 2124 & 13.31 & 0.24 & 12.66 & 3.24 & 11.08 & 0.03 & 0.26 & 27.51 \\
\hline Ovaries* & female & 2 & 2355 & 9.90 & 0.16 & 11.28 & 2.21 & 8.98 & 0.02 & 0.21 & 22.87 \\
\hline Testes* & male & 5 & 2124 & 1.37 & 0.03 & 1.47 & 0.28 & 1.24 & 0.01 & 0.04 & 3.06 \\
\hline Bezdrev & & & & & & & & & & & \\
\hline Muscle & mean & 7 & 2469 & 3.11 & 0.06 & 6.09 & 1.38 & 2.09 & 0.04 & 0.23 & 9.88 \\
\hline & $\mathrm{SD}$ & 1 & 204.6 & 1.58 & 0.03 & 2.40 & 2.38 & 0.88 & 0.02 & 0.08 & 4.84 \\
\hline Liver* & female & 5 & 2522 & 6.50 & 0.11 & 13.13 & 1.32 & 3.75 & 0.08 & 0.48 & 18.87 \\
\hline & male & 2 & 2338 & 3.76 & 0.11 & 8.85 & 0.75 & 2.79 & 0.01 & 0.34 & 12.85 \\
\hline Ovaries* & female & 2 & 2688 & 5.81 & 0.09 & 9.24 & 3.50 & 3.57 & 0.06 & 0.39 & 16.83 \\
\hline Testes* & male & 2 & 2338 & 1.39 & 0.02 & 3.11 & 0.16 & 0.99 & 0.02 & 0.13 & 4.43 \\
\hline
\end{tabular}

Note* - Pooled sample 
Regent (52 ha) - owned by České rybářství s.r.o. Mariánské Lázně. It is situated in cadastre of Holubín village, filled from three independent inflows, last pond in a pond system. A semiintensification pond managed in two-year cycle. A tarmacadam plant is situated nearby the pond. Although it is not in direct contact with the pond, it is in its drainage area. Carp is the main species produced ( $70 \mathrm{t}$ of marketable fish harvested), followed by tench, predatory and herbivorous species.

Tovaryš (16 ha) - owned by Land Fund, hired by Kormorán plus s.r.o. It is situated in cadastre of Sepekov village. Filled from Milevský and Farkův brooks, in areas where is a still persisting intensive agriculture production. A semi-intensification pond managed in annual cycle. Potential sources of industrial pollution in the neighbourhood (air-conditioning works at Milevsko and a tarmacadam plant) are not in a direct contact with the pond but in its drainage area. Carp is the main species produced (10 t of marketable fish harvested), followed by tench, pike and grass carp.

Dřemliny ( 57 ha) - owned by the town Vodňany. It is situated in cadastres of Vodňany town and Číčenice village. Filled from ammelioration system and from overflows of Strpský and Čažárka ponds. Until 1997, it has been used for accumulation of municipal and food processing plant waste water, partly flowing through Čažárka stabilization pond. Later on, waste water were purified at a purification unit and purification was finished in Čažárka pond. The pond is managed in an annual cycle with the majority of carp stock (over 90\%). Ninety tons of carp have been harvested every autumn, while ten tons are harvested during summer catches. Further species produced here involve tench, herbivorous and predatory species.

Horusický (438 ha) - owned by the Rybářství Třeboň a.s. It is situated in cadastre of Horusice village. Filled from three independent inflows, Zlatá stoka, Bukovský brook and Bošilecký pond. It is a semiintensification pond managed in two-year cycle, stocked with ca. 330 thousands of carp stockfish. Harvest of marketable carp is about $500 \mathrm{t}$, supplementary species produced involve tench, predatory and herbivorous species. There is no evidence for any source of direct pollution.

Bezdrev (434 ha) - owned by the Rybníkářství Hluboká a.s. It is in cadastre of Zliv village. It is filled from Bezdrevský brook. It is a semiintensification pond managed in two-year cycle. Carp is the main species produced (harvest of $450 \mathrm{t}$ of marketable carp), further species produced involve predators and herbivorous fish. The pond accumulates purified waste water from purification units at Zliv, Češnovice and Pištín.

Five to seven specimens of three-to-four-year-old carp were sampled from every pond. Immediately after catching, fish were weighed and tissues (muscle, liver, gonads) were sampled. Muscle samples of carp from all ponds under study were sampled and analyzed individually. The same protocol was used for samples of liver, and gonads from the Regent pond. For carp from the other ponds studied, two pooled samples of liver, and gonads were taken and analyzed (one pooled sample of males and one pooled sample of females). Samples were placed in microtene bags, labelled and put into a freezing box at $-18^{\circ} \mathrm{C}$. Bottom sediments were sampled by using a benthos sampler from various parts of the pond. A pooled sample was made and put in a freezing box at $-18^{\circ} \mathrm{C}$ as well.

Tissue samples of marketable carp and samples of bottom sediments were analyzed for the content of persistent organic pollutants (DDT and its metabolites, $\mathrm{HCH}$ isomers, $\mathrm{HCB}, \mathrm{OCS}$ ). Homogenized sample was dessicated by anhydrous sodium sulphate and the flowing powder was extracted by hexane - dichloromethane solvent mixture $(1: 1, \mathrm{v} / \mathrm{v})$ in Soxhlet apparatus. Removing of co-extracted lipids from crude extract was accomplished by gel permeation chromatography (GPC) employing BioBeads SX-3 and chloroform as a mobile phase. After evaporation solvent from GPC fraction and dissolving the residue in isooctane, quantification of target analytes was carried out by high resolution two - dimensional gas chromatography (two capillaries operated in parallel) employing two electron capture detectors (HRGC/2xECD).

Statistical comparison was made for values of content of the respective POPs in muscle of fish from the ponds under study. Results were tested using ANOVA in Statgraphics software. Correlations between the contents of individual POPs in bottom sediments and in fish, as well as between the fat content and content of the POPs in individual tissues of the fish were tested using MS-EXCEL 7.0. In order to interprete the results, hygienic limits concerning fish quoted in the Decree of the Ministry of Health of the Czech Republic No. 298/1997 were used.

Table 3

Contens of DDT and ints metabolites in dry matter of bottom sediments ( $\mathrm{m} \mathrm{g} \mathrm{kg-1}$ ) from the ponds under study

\begin{tabular}{|l|c|c|c|c|c|c|c|}
\hline Pond & o,p-DDE & p,p-DDE & o,p-DDD & p,p-DDD & o,p-DDT & p,p-DDT & $\sum$ DDT \\
\hline Buzický & 0.4 & 43.0 & 2.0 & 12.0 & 0.3 & 2.0 & 59.7 \\
\hline Regent & 0.8 & 8.3 & 5.6 & 16.7 & 1.4 & 2.8 & 4.2 \\
\hline Tovaryš & 0.75 & 85.63 & 12.80 & 36.54 & 2.11 & 5.62 & 143.45 \\
\hline Dřemliny & 0.23 & 1.36 & 0.25 & 1.07 & 0.12 & 0.37 & 3.41 \\
\hline Horusický & 0.23 & 4.67 & 2.68 & 4.96 & 0.17 & 0.34 & 13.05 \\
\hline Bezdrev & BDL* & 0.33 & BDL* & 0.36 & BDL* & BDL* $^{*}$ & 0.69 \\
\hline
\end{tabular}


Table 2

Contents of $\mathrm{HCH}, \mathrm{HCB}$ and OCS in tissues $\left(\mu \mathrm{g} \cdot \mathrm{kg}^{-1}\right.$ w.w.) of marketable carp from the ponds under study

\begin{tabular}{|c|c|c|c|c|c|c|c|c|c|c|}
\hline Pond Tissue & & $\mathrm{n}$ & Body mass in $\mathrm{g}$ & Fat $(\%)$ & HCB & OCS & $\alpha-\mathrm{HCH}$ & $\beta$-HCH & $\gamma-\mathrm{HCH}$ & $\sum \mathrm{HCH}$ \\
\hline \multicolumn{11}{|l|}{ Buzický } \\
\hline \multirow[t]{2}{*}{ Muscle } & mean & \multirow{2}{*}{5} & 2164 & 7.54 & 3.11 & 0.30 & 0.44 & 3.56 & 2.33 & 6.33 \\
\hline & SD & & 261.2 & 2.58 & 3.49 & 0.11 & 0.22 & 2.15 & 2.84 & 3.84 \\
\hline Liver* & mean & 5 & 2164 & 15.79 & 8.69 & 2.05 & 0.79 & 6.00 & 5.48 & 12.63 \\
\hline Ovaries* & female & 3 & 2210 & 8.62 & 1.98 & 0.17 & 0.06 & 0.06 & 0.34 & 0.46 \\
\hline Testes* & male & 2 & 2090 & 1.12 & 0.35 & 0.08 & 0.09 & 0.09 & 0.11 & 0.29 \\
\hline \multicolumn{11}{|l|}{ Regent } \\
\hline \multirow[t]{2}{*}{ Muscle } & mean & \multirow{2}{*}{6} & 3157 & 10.70 & 5.07 & 0.44 & 0.39 & 1.25 & 1.50 & 3.13 \\
\hline & SD & & 408.7 & 4.07 & 1.99 & 0.25 & 0.29 & 1.12 & 1.44 & 2.83 \\
\hline \multirow[t]{2}{*}{ Liver } & mean & \multirow{2}{*}{7} & 3236 & 11.63 & 9.18 & 1.34 & 3.71 & 8.58 & 2.60 & 14.89 \\
\hline & $\mathrm{SD}$ & & 427.7 & 6.22 & 4.62 & 0.69 & 2.32 & 4.85 & 0.90 & 7.08 \\
\hline Kidney* & mean & 7 & 3236 & 6.11 & 3.48 & 0.18 & 0.18 & 2.51 & 0.24 & 2.93 \\
\hline \multirow[t]{2}{*}{ Ovaries } & mean & \multirow{2}{*}{4} & 3239 & 6.00 & 4.02 & 0.49 & 1.18 & 3.14 & 1.17 & 5.48 \\
\hline & $\mathrm{SD}$ & & 587.5 & 3.77 & 2.61 & 0.51 & 1.94 & 2.61 & 1.90 & 6.39 \\
\hline \multirow[t]{2}{*}{ Testes } & mean & \multirow{2}{*}{3} & 3232 & 2.93 & 2.68 & 0.32 & 0.27 & 4.39 & 0.77 & 5.43 \\
\hline & $\mathrm{SD}$ & & 176.2 & 1.44 & 0.88 & 0.21 & 0.14 & 0.47 & 0.55 & 0.60 \\
\hline \multicolumn{11}{|l|}{ Tovaryš } \\
\hline \multirow[t]{2}{*}{ Muscle } & mean & \multirow{2}{*}{7} & 1689 & 4.26 & 6.17 & 0.80 & 0.04 & 0.19 & 0.31 & 0.54 \\
\hline & SD & & 181.1 & 1.47 & 2.25 & 0.25 & 0.03 & 0.06 & 0.08 & 0.17 \\
\hline \multirow[t]{2}{*}{ Liver* } & female & 4 & 1673 & 9.73 & 15.42 & 1.80 & 0.05 & 0.38 & 0.51 & 0.93 \\
\hline & male & 3 & 1710 & 13.34 & 21.93 & 2.71 & 0.11 & 0.58 & 0.87 & 1.56 \\
\hline Testes* & male & 3 & 1710 & 2.37 & 4.07 & 0.41 & 0.02 & 0.13 & 0.18 & 0.34 \\
\hline \multicolumn{11}{|l|}{ Dřemliny } \\
\hline \multirow{2}{*}{ Muscle } & mean & \multirow{2}{*}{7} & 1980 & 5.10 & 1.05 & 0.02 & 0.06 & 0.11 & 0.23 & 0.40 \\
\hline & $\mathrm{SD}$ & & 276.5 & 1.58 & 0.26 & 0.01 & 0.03 & 0.06 & 0.05 & 0.13 \\
\hline \multirow[t]{2}{*}{ Liver* } & female & 3 & 1775 & 4.09 & 0.79 & 0.01 & 0.10 & 0.06 & 0.19 & 0.35 \\
\hline & male & 4 & 2134 & 3.11 & 0.60 & 0.04 & 0.04 & 0.20 & 0.20 & 0.45 \\
\hline Ovaries* & female & 3 & 1775 & 4.15 & 0.69 & 0.01 & 0.04 & 0.09 & 0.25 & 0.38 \\
\hline Testes* & male & 4 & 2134 & 0.67 & 0.24 & 0.00 & 0.01 & 0.03 & 0.09 & 0.13 \\
\hline \multicolumn{11}{|c|}{ Horusický } \\
\hline \multirow[t]{2}{*}{ Muscle } & mean & 7 & 2190 & 4.39 & 0.31 & 0.02 & 0.03 & 0.05 & 0.11 & 0.20 \\
\hline & $\mathrm{SD}$ & & 166.8 & 1.68 & 0.09 & 0.01 & 0.01 & 0.02 & 0.03 & 0.05 \\
\hline Liver* & female & 2 & 2355 & 9.92 & 0.85 & 0.06 & 0.02 & 0.22 & 0.29 & 0.53 \\
\hline & male & 5 & 2124 & 13.31 & 0.96 & 0.03 & 0.10 & 0.34 & 0.37 & 0.80 \\
\hline Ovaries* & female & 2 & 2355 & 9.90 & 0.85 & 0.02 & 0.06 & 0.11 & 0.19 & 0.36 \\
\hline Testes* & male & 5 & 2124 & 1.37 & 0.15 & 0.01 & 0.01 & 0.03 & 0.08 & 0.12 \\
\hline Bezdrev & & & & & & & & & & \\
\hline Muscle & mean & 7 & 2469 & 3.11 & 0.54 & 0.02 & 0.03 & 0.06 & 0.14 & 0.24 \\
\hline & $\mathrm{SD}$ & 1 & 204.6 & 1.58 & 0.24 & 0.01 & 0.02 & 0.02 & 0.04 & 0.08 \\
\hline Liver* & female & 5 & 2522 & 6.50 & 1.09 & 0.06 & 0.09 & 0.30 & 0.34 & 0.73 \\
\hline & male & 2 & 2338 & 3.76 & 0.71 & 0.01 & 0.02 & 0.08 & 0.24 & 0.34 \\
\hline Ovaries* & female & 2 & 2688 & 5.81 & 0.88 & 0.05 & 0.05 & 0.07 & 0.19 & 0.32 \\
\hline Testes* & male & 2 & 2338 & 1.39 & 0.31 & 0.01 & 0.02 & 0.03 & 0.10 & 0.15 \\
\hline
\end{tabular}

Note* - Pooled sample 
Table 4

Contens of $\mathrm{HCB}$, OCS and $\mathrm{HCH}$ in dry matter of bottom sediments ( $\mathrm{g} \mathrm{kg}^{-1}$ ) from the ponds under study

\begin{tabular}{|l|c|c|c|c|c|c|}
\hline Pond & HCB & OCS & $\alpha-\mathrm{HCH}$ & $\beta-\mathrm{HCH}$ & $\gamma-\mathrm{HCH}$ & $\sum-\mathrm{HCH}$ \\
\hline Buzický & 0.40 & 0.60 & 0.90 & 1.70 & 1.30 & 3.90 \\
\hline Regent & 5.60 & 2.80 & 1.40 & 2.20 & 1.90 & 5.50 \\
\hline Tovaryš & 7.03 & 0.70 & 0.15 & 0.55 & 0.50 & 1.20 \\
\hline Dřemliny & 0.85 & 0.19 & 0.12 & 0.09 & 0.17 & 0.39 \\
\hline Horusický & 0.37 & 0.11 & 0.11 & 0.48 & 0.43 & 1.03 \\
\hline Bezdrev & 0.42 & BDL* & 0.07 & 0.14 & 0.13 & 0,34 \\
\hline
\end{tabular}

Note* - Below Det. Limit

\section{Results}

Values of DDT and its metabolites, HCH isomers, HCB and OCS in tissues ( $\mu \mathrm{g} \cdot \mathrm{kg}^{-1}$ wet weight) of marketable carp from ponds under study are given in Tables 1 and 2. Comparison of these compounds in muscle of marketable carp from ponds under study is shown in Figs 2, 3 and 4 . Tables 3 and 4 report POPs contents in dry matter of bottom sediments from the respective ponds.

\section{DDT and its metabolites}

With respect to the content of individual DDT metabolites in muscle and in other tissues of marketable carp, the following sequence could be generally presented: $p, p-$ DDE $>p, p$ DDD $>0, p-$ DDD $>$ p,p-DDT $>0, p-D D E>0, p-D D T$. Among metabolites with chlorine located in the p,p position on hydrocarbon, the metabolite p,p - DDE highly predominated. This information was valid for carp from the Buzický, Tovaryš, Dřemliny and Bezdrev ponds. The contents of p,p - DDE and p,p - DDD metabolites were almost the same in carp tissues from the Horusický pond. The content of $\mathrm{p}, \mathrm{p}$ - DDD metabolite was even higher compared with the content of p,p - DDE metabolite in carp tissues from the Regent pond.

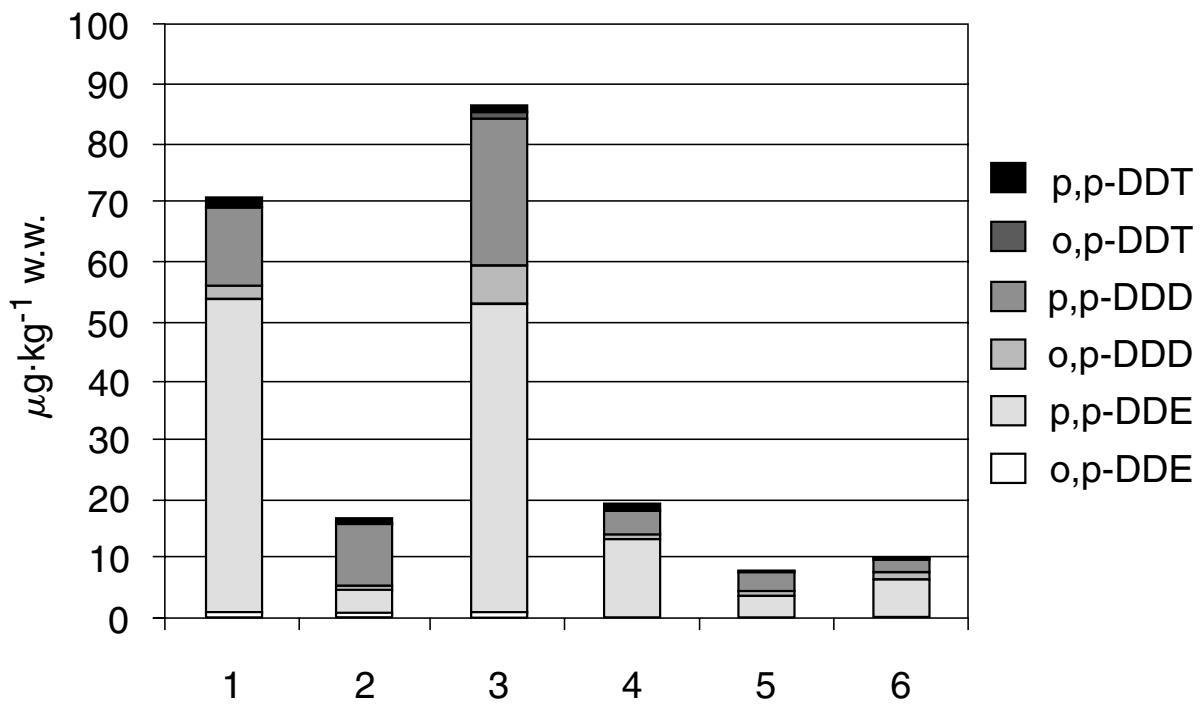

Fig. 2. Comparison of the contents of DDT in muscle of marketable carp from the ponds under study (1-Buzický, 
The sequence of monitored ponds according to the sum of DDT and its metabolites in the muscle of marketable carp was as followed: Tovaryš $>$ Buzický $>$ Dřemliny $>$ Regent $>$ Bezdrev $>$ Horusický. The sum of DDT and its metabolites was higher $(p<0.01)$ in the Tovaryš and Buzický ponds in comparison with values found in carp from other ponds under study. Summary values of DDT and its metabolites in carp muscle from the Tovaryš and Buzický ponds were comparable, without any significant difference. Neither differences in DDT and its metabolites content in carp muscle from the Regent, Dřemliny, Bezdrev and Horusický ponds were significant. The content of $\mathrm{p}, \mathrm{p}-$ DDE metabolite followed the values and differences found in content of DDT sum and of its metabolites.

Usually the content of DDT and of its metabolites was found to be the highest in liver, followed by muscle and eggs. The lowest values were found for testes in all cases. Statistical assessment of the results revealed a close correlation of the content of the sum of DDT and of its metabolites on fat content in individual tissues of fish originating from one and the same pond $(r=0.929-0.999)$.

In fact, the proportion of individual DDT metabolites in bottom sediments followed their pattern in fish tissues. The highest values have been found for metabolites $p, p-$ DDE, followed by $p, p-$ DDD, o,p - DDD, p,p - DDT and others. The values of metabolites p,p - DDE and p,p - DDD in bottom sediments in the Horusický pond were almost identical. In bottom sediments of the Regent pond, the level of p,p - DDD was approximately doubled in comparison with p,p-DDE values. The highest values of the sum and of individual metabolites were found in the Tovaryš and Buzický ponds, more than ten times lower and comparable values were recorded in the bottom sediments of other monitored ponds.

In conclusion, a generally low proportion of maternal compounds of the p,p- DDT type indicated, contrasting to the corresponding metabolites content, that the application of this type of insecticide preparations has been performed before several decades already. Thus, this was an old load. Actually, the process of biotransformation in persistent compounds discussed above was very slow.

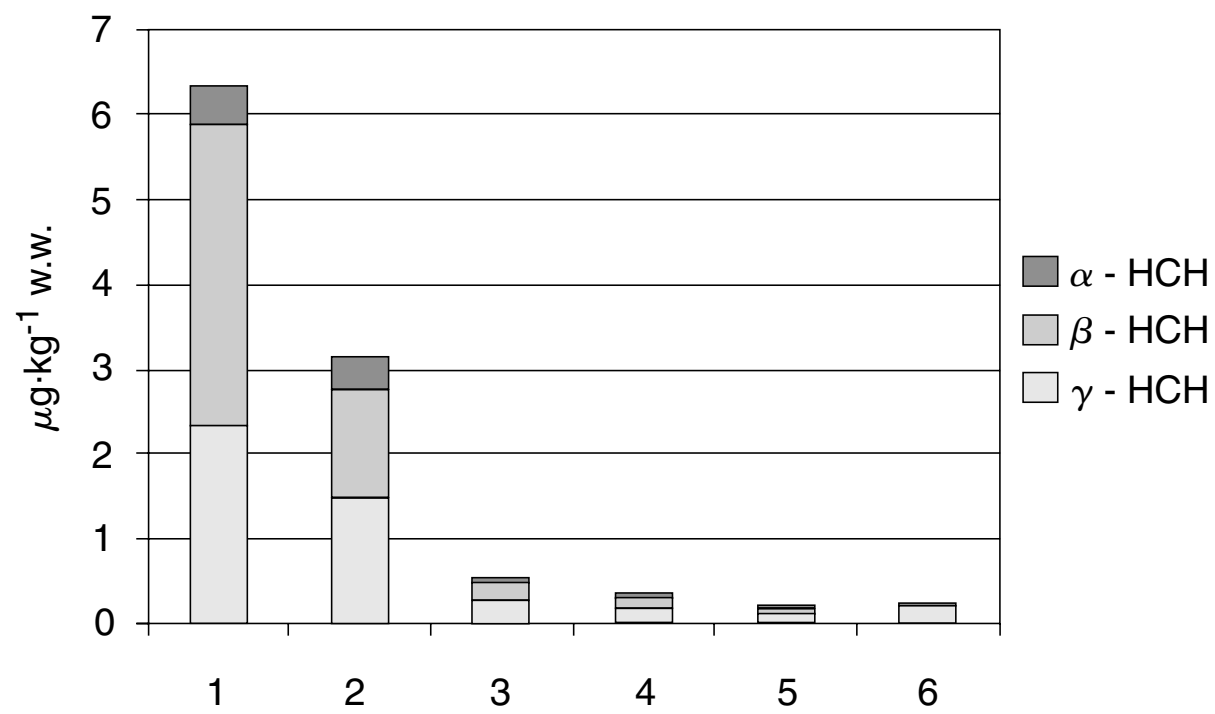

Fig. 3. Comparison of the contents of $\mathrm{HCH}$ isomers in muscle of marketable carp from the ponds under study (1Buzický, 2-Regent, 3-Tovaryš, 4-Dřemliny, 5-Horusický, 6-Bezdrev) 
$\mathrm{HCH}$ - isomers

The sequence of monitored ponds regarding individual $\mathrm{HCH}$ isomers and their sum in the muscle of marketable carp was as follows: Buzický $>$ Regent $>$ Tovaryš $>$ Dřemliny $>$ Bezdrev > Horusický. In carp from the Buzický and Regent ponds, the sum of $\mathrm{HCH}$ isomers was higher ( $p<0.01$ and $p<0.05$, respectively) compared with values found in carp from other ponds under observation. The values of the content of individual $\mathrm{HCH}$ isomers followed the values and differences found for the $\mathrm{HCH}$ sum. It meant a significant difference $(p<0.01$ and $p<0.05$, respectively) in most cases concerning the values of $\alpha-\mathrm{HCH}, \beta-\mathrm{HCH}$ and $\gamma-\mathrm{HCH}$ between the carp muscle from the Buzický and Regent ponds on one hand, and carp muscle from the other monitored ponds on the other hand.

The proportion of individual $\mathrm{HCH}$ isomers in muscle and in other tissues was different in marketable carp with higher and lower level of load. The sequence of isomers in ponds with higher level of load (Buzický, Regent ponds) was as follows: $\beta$ - $\mathrm{HCH}>\gamma-\mathrm{HCH}>\alpha-\mathrm{HCH}$ whereas in those with lower level of load (Tovaryš, Dřemliny, Bezdrev, Horusický ponds), the sequence was the following: $\gamma-\mathrm{HCH}>\beta-\mathrm{HCH}>\alpha-\mathrm{HCH}$. These findings may indicate different sources of contamination or different time of contamination (Saunders and Harper 1994).

In the majority of cases, the content of $\mathrm{HCH}$ isomers was the highest in liver, followed by muscle and eggs. The lowest values were found for testes in all cases. Statistical assessment of the results revealed a close correlaton of the content of $\mathrm{HCH}$ isomers on fat content in individual tissues of fish originating from one and the same pond $(r=0.810-0.980)$.

Also according to the results of bottom sediment analyses as for the content of $\mathrm{HCH}$ isomers, the monitored ponds can be divided into two groups, namely ponds with higher (Regent and Buzický ponds) and lower level of load (Tovaryš, Horusický, Dřemliny and Bezdrev). In ponds with higher load level, the highest content was found in b-HCH isomer. In ponds with lower load level, the content of $\beta-\mathrm{HCH}$ and $\gamma-\mathrm{HCH}$ isomers was almost the same.

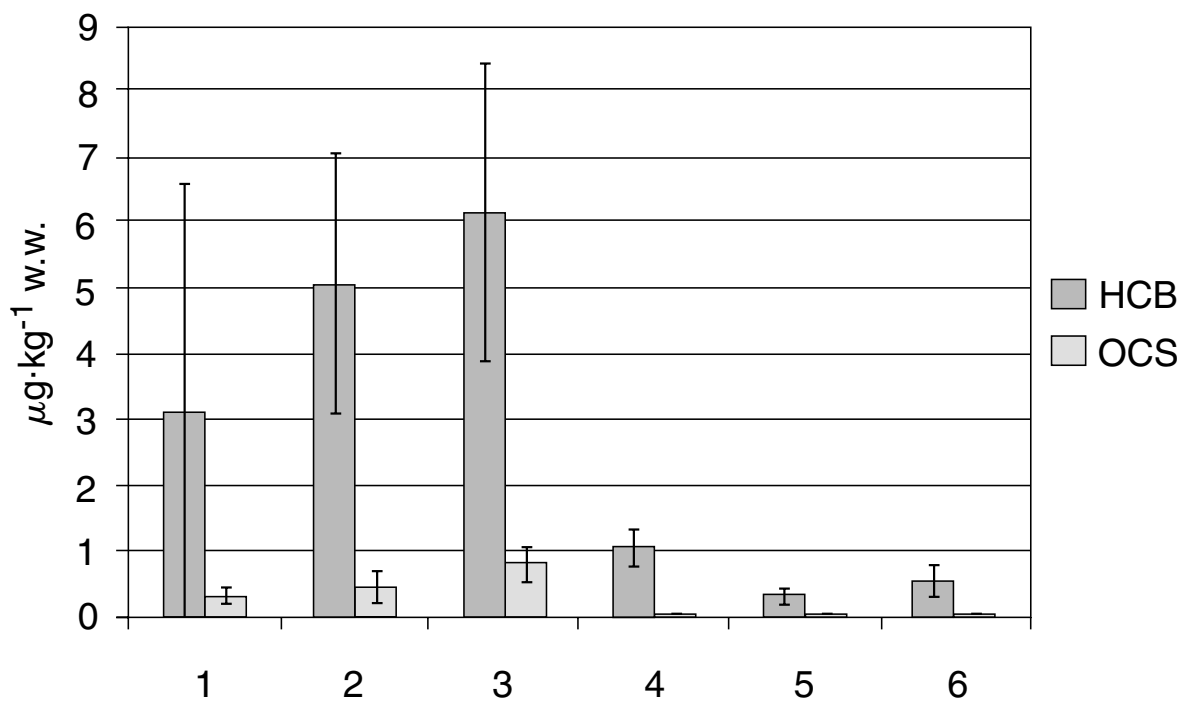

Fig. 4. Comparison of the contents of HCB and OCS in muscle of marketable carp from the ponds under study (1-Buzický, 2-Regent, 3-Tovaryš, 4-Dřemliny, 5-Horusický, 6-Bezdrev) 


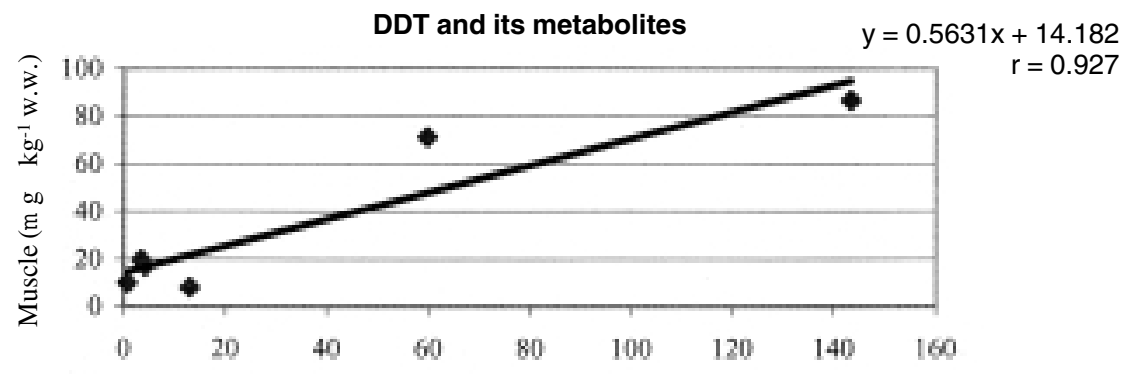

Bottom sediments (mg kg-1 dry matter)

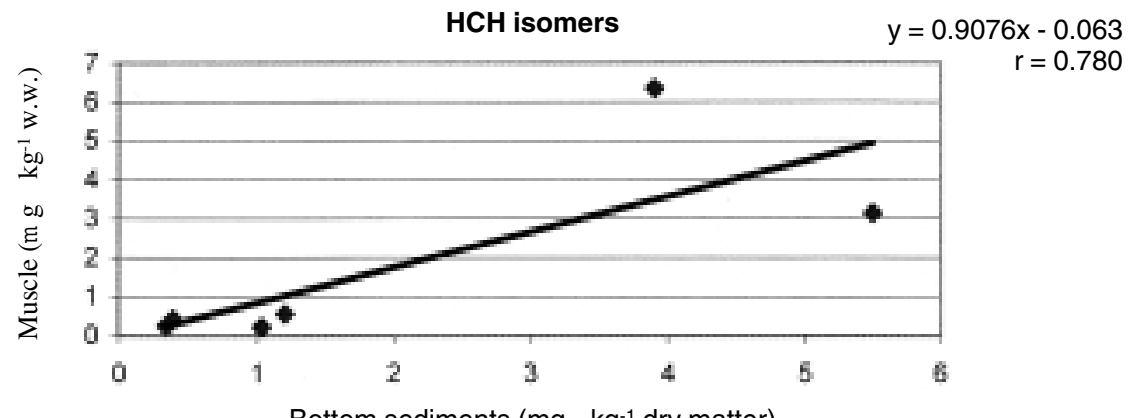

Bottom sediments (mg kg-1 dry matter)
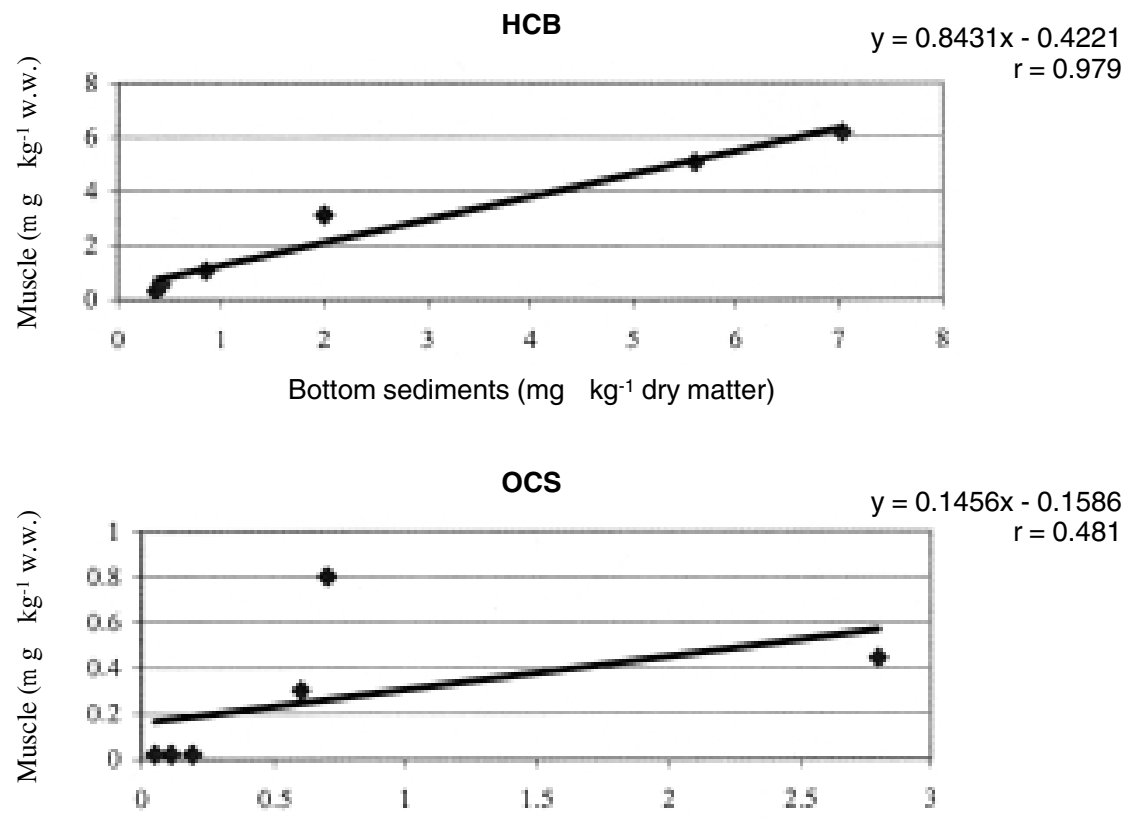

Bottom sediments (mg kg-1 dry matter)

Fig. 5. Correlation between the contents of monitored POPs in bottom sediment and carp muscle 


\section{$\mathrm{HCB}$}

The sequence of monitored ponds as for the HCB content in the muscle of marketable carp was as follows: Tovaryš $>$ Regent $>$ Buzický $>$ Dřemliny $>$ Bezdrev $>$ Horusický. A significant difference $(p<0.01)$ was found when comparing the HCB values in muscle of carp from ponds with higher load level (Tovaryš and Regent) and in the muscle of carp from ponds with lower load level (Dřemliny, Bezdrev and Horusický).

In the majority of cases, the content of HCB was the highest in liver, followed by muscle and eggs. The lowest values were found for testes in all cases. Statistical assessment of the results revealed a close correlation of the $\mathrm{HCB}$ content on fat content in individual tissues of fish originating from one and the same pond $(r=0.939-0.998)$.

The sequence of ponds as for the level of HCB in bottom sediments was identical with the sequence mentioned for the carp muscle, i.e. the following: Tovaryš > Regent >Buzický > Dřemliny $>$ Bezdrev $>$ Horusický.

\section{OCS}

The monitored ponds could be divided into two groups based on the results of OCS assessment in muscle and other tissues of marketable carp. The first group comprised ponds with higher load level (Tovaryš, Regent, Buzický), while the second group included those with low load level (Dřemliny, Horusický, Bezdrev). A significant difference $(p<0.01)$ was found between the values of OCS in carp muscle of both groups. Higher $(p<0.01)$ values were found also in muscle of carp from the Tovaryš pond compared with the values recorded in carp muscle from the Regent and Buzický ponds.

In the majority of cases, the content of OCS was the highest in liver, followed by muscle and eggs. The lowest values were found for testes in all cases. In fish from the Tovaryš, Bezdrev and Buzický ponds, statistical assessment of the results revealed a close correlation of the OCS content on fat content in individual tissues $(r=0.869-0.998)$ while a median correlation was found for fish from Horusický and Regent ponds $(r=0.550-0.693)$. No such relationship was proven for fish from the Dřemliny pond $(\mathrm{r}=0.22)$.

Also as for the OCS content in the bottom sediment, the monitored ponds could be divided into two groups - those with higher (Regent, Tovaryš, Buzický) and lower load levels (Dřemliny, Horusický, Bezdrev).

\section{Discussion}

Two components were employed for indication of the load level by persistent organic pollutants (POPs) in six selected ponds of the South and West Bohemia region: the abiotic component represented by bottom sediments and the biotic one - fish tissues. They have been cultured in monitored ponds for a period of one (in one-season ponds - Buzický, Tovaryš, Dřemliny) or two years (in two-seasons ponds - Regent, Horusický, Bezdrev).

Regarding the individual monitored POPs, results of analyses of tissue and bottom sediments were comparable and they allowed an explicit separation between ponds with higher and lower load levels. The Tovaryš and Buzický ponds were set as the ponds with higher load level of DDT and its metabolites; the Regent and Buzický ponds as the ponds with higher load with $\mathrm{HCH}$ isomers and the Tovaryš, Regent and Buzický ponds were found as ponds with higher loads with HCB and OCS. Figure 5 shows a correlation between the content of individual POPs studied in bottom sediments and in muscle of marketable common carp from the ponds monitored. High correlation coefficient was found for the sum of DDT and metabolites $(r=0.93)$ and for $\mathrm{HCB}(\mathrm{r}=0.98)$. Median correlation was proven for the sum of $\mathrm{HCH}$ isomers $(\mathrm{r}=0.78)$ and a slight one for the OCS $(\mathrm{r}=0.48)$. The results proved high and comparable indication suitability of fish tissues and bottom sediments for evaluation of pond load by DDT and its metabolites, $\mathrm{HCH}$ isomers and $\mathrm{HCB}$ and OCS. 
Moreover, their convenience as indicators of pond contamination was supported by their easy availability - during pond harvest (fish) and afterwards (bottom sediments).

The results of carp tissues from one-season ponds (Buzický and Tovaryš) documented that also a short-time fish residence in this environment enabled indication of its load. In oneseason system of management, carp were stocked in April and harvested in November. This means that the time fish residence took maximum $7-8$ months.

In compliance with the proportion of individual monitored persistent organic pollutants in carp tissues and botom sediments, the prevailing source of contamination could be determined. The higher load levels of HCB and OCS, i.e. industrial load, was proven in the Tovaryš, Regent and Buzický ponds. These were ponds trapping municipal waste waters from settlements with significant industry (Blatná town - Buzický pond) or ponds, the catchment areas of which hold important industrial facilities or tarmacadam plants (Tovaryš, Regent). A higher contamination by $\mathrm{HCH}$ isomers and above all by DDT and its metabolites was proven in carp tissues and in bottom sediments from pond with extensive catchment area and intensive agriculture production. This concerned also the Tovaryš and Regent ponds but particularly the Buzický pond. However, the long-range transport and atmospheric imissions also played a significant role.

The comparison and interpretation of these results was restricted due to the absence of literatura data. Also comparison of monitored POPs in tissues of pond-cultured and ,wild“ carp was not relevant. Actually, carp stocks in natural water bodies comprised fish cultured in different ponds for 2-4 years and thus they could not be considered as indicator fish from natural waterbodies. Also data from other countries about POPs content in carp tissues are very scarce. It is to say that marketable pond carp production is a speciality particularly of Central and East Europe (V ách a 1998). For comparison, the available data about HCB and DDT sum in muscle of indicator cyprinid fish in the lower stretch of the Elbe river in area of the Czech Republic were presented by S vobodova et al. (1993b). The HCB values in muscle of chub, barbel and bream ranged between 116-647, 120-649 and 243-565 $\mu \mathrm{g} \cdot \mathrm{kg}^{-1}$ w.w., respectively. The DDT sum in the muscle of chub, barbel and bream ranged from 165$1031,237-1157$ and $342-450 \mu \mathrm{g} \cdot \mathrm{kg}^{-1}$ w.w. respectively. The HCB values in carp muscle from the monitored ponds are approximately by 100-1000 times lower in comparison with the data from cyprinids from the Elbe river. Also the values of DDT sum in pond-cultured marketable carp are 1000-10000 times lower. It can be observed that fish production in farm ponds is safe (there are neither any emission sources nor significant old loads there) and provides minimum dietary exposure to consumers.

In general, the results presented in the study correspond to the results of analyses of carp tissues and bottom sediments from 4 selected ponds (Ruda, Spolský, Labská and Újezdský) in area of the Czech Republic in 1980 (Svobodová et al. 1983b). Particularly good agreement was found for proportion of the DDT and its metabolites in fish tissues: DDE > DDD > DDT. Among HCH isomers, the $\gamma-$ and $\alpha$-isomers prevailed, however b isomer was not detected. As for the distribution in tissues, higher content of DDT and its metabolites, HCB and $\mathrm{HCH}$ isomers was found in liver as compared to muscle.

The results of marketable carp muscle from the Buzický, Dřemliny and Regent ponds, performed in 1992, have been compared with results achieved on the same ponds in 1999 and 2000 (Randák et al. 2001a, 2001b; Žlábek et al. 2002). Significant $(p<0.05)$ increase was found for DDT and its metabolites and HCH isomers as for 1999 in Buzický pond. Its reason was probably in re-availability of old loads. On the contrary, a decrease $(p<0.01)$ in content of DDT and its metabolites in muscle of marketable carp from the Regent pond was proven in 2000 as compared to 1992.

The monitored POPs are lipophilic and their accumulation is influenced to a certain extent by fat content in fish tissues. This fact was confirmed by statistical assessment of the results. 
The highest correlation coefficients for contents of all the POPs studied in individual tissues in relationship with fat content were proven for fish captured from the Tovaryš pond $(\mathrm{r}=$ $0.980-0.999$ ) which is mostly loaded with the given pollutants.

The Directive of the Czech Ministry of Health No.298/1997 gives the upper limits of residues, i.e. the highest permissible toxicologically acceptable amount of pesticides in fish (in $\mu \mathrm{g} \cdot \mathrm{kg}^{-1}$ w.w.): sum of DDT and its metabolites 500; $\gamma$ - isomer HCH 50; sum of HCH isomers apart from $\gamma$-isomers 20; HCB 50. When comparing the values recorded in tissues of marketable carp from six monitored ponds with these limits, we could declare that carp from all ponds satisfied these hygienic requirements. Even in a range of cases, the recorded POPs values were several times lower, particularly those found in the Dřemliny, Horusický and Bezdrev ponds.

The ADI (Acceptable Daily Intake) values as assigned by WHO for the year 2001 for individual determined pollutants are as follows $\left(\mu \mathrm{g} \cdot \mathrm{kg}^{-1}\right.$ day $\left.^{-1}\right)$ : DDT and its metabolites $20, \mathrm{HCB} 0.6$ and $\mathrm{HCH} \gamma$ - isomer 1. Only ponds with the highest values of the content of these pollutants were selected for further evaluation of the hygienic risk, i.e. the Tovarys pond for the evaluation of DDT and its metabolites and of HCB, and the Buzický pond for the evaluation of $\mathrm{HCH} \gamma$ - isomer. To achieve the ADI for DDT and its metabolites, a 70-kg man should have to consume $16.2 \mathrm{~kg}$ of carp flesh per day. In case of $\mathrm{HCB}$ and $\mathrm{HCH} \gamma-$ isomer, the corresponding amounts should have to be $6.8 \mathrm{~kg}$ and $30 \mathrm{~kg}$ of flesh per day, respectively. The mean yearly freshwater fish consumption in the Czech Republic amounts to $1 \mathrm{~kg}$ per capita (Berka 1998), which represents $2.74 \mathrm{~g} \mathrm{day}^{-1}$. When assuming the consumption of fish from the most loaded ponds, the consistency percentages with ADI values were $0.017,0.04$ and $0.009 \%$ for DDT and its metabolites, $\mathrm{HCB}$ and $\mathrm{HCH} \gamma$ isomer, respectively (Kannan 1998). Thus the minimal risk of dietary exposure to monitored POPs results from the outcomes of both evaluations.

\section{Obsah perzistentních organochlorovaných polutantů (POPs) v tkáních tržních kaprů obecných a sedimentech dna vybraných rybníků jižních a západních Čech}

Cílem práce bylo posoudit stav vybraných rybníků jižních a západních Čech z hlediska kontaminace vybranými POPs (DDT a jeho metabolity, izomery $\mathrm{HCH}, \mathrm{HCB}$ a OCS). V podzimním období 1999 - 2001 bylo vyšetř̌eno 6 rybníků, z každého byl odebrán vzorek sedimentu a 5 až 7 kusů tržních kaprů (svalovina, játra, gonády). Ve svalovině (v čerstvé tkáni) ryb byl zjištěn obsah DDT a jeho metabolitù v rozmezí 7,91 až $86,48 \mu \mathrm{g} \cdot \mathrm{kg}^{-1}$, suma izomerů HCH 0,20 až 6,33 $\mu \mathrm{g} \cdot \mathrm{kg}^{-1}$, HCB $0,31 \mathrm{až} 6,17 \mu \mathrm{g} \cdot \mathrm{kg}^{-1}$ a OCS $0,02 \mathrm{až} 0,80 \mu \mathrm{g} \cdot \mathrm{kg}^{-1}$. Výsledky ukázaly srovnatelnou indikační schopnost tkání ryb a sedimentů dna pro posuzování zatížení rybníků sledovanými POPs. Korelační koeficienty mezi jejich obsahem v sedimentech dna a ve svalovině ryb byly následující: $r=0,927$ pro sumu DDT a jeho metabolitů; $r=0,780$ pro izomery $\mathrm{HCH} ; \mathrm{r}=0,979$ pro $\mathrm{HCB} ; \mathrm{r}=0,481$ pro OCS. Míra zátěže rybníků odpovídala intenzitě zemědělské a průmyslové výroby v jejich povodí. Byla rovněž prokázána vysoká závislost $(\mathrm{r}=0,810$ - 0,999) obsahu DDT, HCH a HCB na obsahu tuku v jednotlivých tkáních ryb pocházejících z jednoho rybníka. Žádná z naměřených hodnot sledovaných POPs nepřekročila maximální limit reziduí stanovený legislativními předpisy. Předložená práce je příspěvkem ke zhodnocení kvality kaprů - hlavních zástupců tržních ryb na území ČR a ke zhodnocení jejich životního prostředí. Práce tak přispívá k naplňování strategie bezpečnosti potravin.

\section{Acknowledgements}

This research was supported by the Ministry of Education, Youth and Physical Training of the Czech Republic (MSM Project No. 126100003) and Ministry of Agriculture of the Czech Republic (Department of Food Production). 


\section{References}

AUGUSTIJN-BECKERS, PWM, HORNSBY, AG, WANCHOPE, RD 1994: Pesticide properties database for environmental decision making. II. Additional compounds. Rev Environ Contam Toxicol 137: 1-82

BERGMAN, A, LARSSON, C, GUVENIUS, DM 2002: Origin and fate of persistent PCB metabolites: $\mathrm{MeSO}_{2}-$ PCB and OH - PCB. The Second PCB Workshop, Masaryk University Brno, p. 87

BERKA, R 1998: Sladkovodní ryby - co s nimi dál. Výživa a potraviny 53:106-107

BESTER, K, BISELLI, S, ELLERICHMANN, T, HUHNERFUSS, H, MOLLER, K, RIMKUS, G, WOLF, M 1998: Chlorostyrenes in fish and sediment samples from the river Elbe. Chemosphere 37: 2459-2471

CARSON, R 1962: Silent spring. Honghton - Mifflin, Boston, MA, 368 p.

CLARK, RB 1992: Marine pollution. 3rd Edition Clarendon Press Oxford, 172 p.

DUFFUS, JH 1980: Environmental Toxicology: resource and environmental sciences series. Halsted Press, John Wiley and Sons, New York, $164 \mathrm{p}$.

GUPTA, RC, ROBERTSON, LW 2002: DNA damage from PCB exposure. The Second PCB Workshop, Masaryk University Brno, p. 88

HAJŠLOVÂ, J, SCHOULA, R, KOCOUREK, V, HOLADOVÁ, K, POUSTKA, J, KOHOUTKOVÁ, J, SVOBODOVÁ, Z 1997: Polychlorinated biphenyls and other persistent chlorinated contaminants in fish as indicators of pollution of aquatic ecosystem in Czech Republic. Toxicol Environ Chem 59: 279-291

HESELTINE, E (Ed.) 2001: Pesticide residues in food - 2002, part II - toxicological evaluations. Joint FAO/WHO Meeting on Pesticide Residues, WHO, 272 p.

IWATA, H, TANABE, S, SAKAL, N, TATSUKAWA, R 1993: Distribution of persistent organochlorines in the oceanic air and surface seawater and the role of ocean on their global transport and fate. Environ Sci Technol 27: $1080-1098$

JOHNSON, WW, FINLEY, MT 1980: Handbook of acute toxicity of chemicals to fish and aquatic invertebrates. Resource Publication 137, U.S. Department of Interior, Fish and Wildlife Service, Washington, DC.

JORGENSEN, EH, BURKOW, IC, FOSHAUG, H, KILLIE, B, INGEBRIGTSEN, K 1997: Influence of lipid status on tissue distribution of the persistent organic pollutant octachlorostyrene in Arctic charr (Salvelinus alpinus). Comp Bioch Physiol C, Pharmacol Toxicol Endocrinol 118: 311-318

KAMINSKY, R, HITES, RA 1984: Octachlorostyrene in Lake Ontario: sources and fates. Environ Sci Technol 18 : 275-279

KANNAN, K, SMITH, RG, LEE, RF, WINDOM, HL, HEITMULLER, PT, MACAULEY, JM, SUMMERS, JK 1998: Distribution of total mercury and methyl mercury in water, sediment, and fish from south Florida estuaries. Arch Environ Contam Toxicol 34:109-118

KAVLOCK, RJ, DASTON, DP, DEROSA, CH, FENNER-CRISP, P, GRAY, LE, KAATTARI, S, LUCIER, G, LUSTER, M, MAC, MJ, MACZKA, C, MILLER, R, MOORE, J, ROLLAND, R, SCOTT, G, SHEEHAN, DM, SINKS, T, TILSON, HA 1996: Research needs for the risk assessment of health and environmental effects of endocrine disruptors: A Report of the U.S. EPA - sponsored Workshop. Environ Health Perspec 104: 1-26

KEITH, LH 1997: Environmental endocrine disruptors. John Wiley and Sons Inc, New York, 1232 p.

KINLOCH, D, KUHNLEIN, H, MUIR, DCG 1992: Inuit foods and diet- a preliminary assessment of benefics and risks. Sci Total Environ. 122: 247-278

KREDL, F, SVOBODNÍK, J, SVOBODOVÁ, Z 1989: Residues of chlorinated pesticides and polychlorinated biphenyls in fish coming from different localities in the Czech Republic. Vet Med (Praha) 34: 239-250

LAKOTA, S, RASZKA, A, ROSZKOWSKI, J, HLOND, S, KOZLOWSKI, F 1983: Toxic effects of DDT, lindane, and toxaphene on the fry of the carp, Cyprinus carpio, as revealed by an acute test. Folia Biol 31: 93-99

MERTLÍK, J, SVOBODOVÁ, Z 1973: Toxicity of pesticides on the base of chlorinated carbohydrates and phenols and their indication in fish. Bulletin VÚRH Vodňany 9: 3-18

NORSTROM, RJ, MUIR, DCG 1997: Chlorinated-hydrocarbon contaminants in Arctic marine mammals. Sci Total Environ 154: 107-128

RANDÁK, T, SVOBODOVÁ, Z, REITINGER, A 2001a: Comparison of the content of foreign substances in tissues of carp (Cyprinus carpio L.) and in bottom sediments of the Dřemliny pond in 1991-1992 and 1999. Bulletin VÚRH Vodňany 37: 8-22

RANDÁK, T, SVOBODOVÁ, Z, REITINGER, A 2001b: Comparison of the content of foreign substances in tissues of carp (Cyprinus carpio L.) and in bottom sediments of the Buzický pond in 1991-1992 and 1999. Bulletin VÚRH Vodňany 37: 47-59

SAUNDERS, DS, HARPER, C 1994: Pesticides. Principles and Methods of Toxicology (ed. W. Hayes), Raven Press, Ltd., New York, 389-415

SVOBODOVÁ, Z, HRBKOVÁ, M, FAINA, R, MÁCHOVÁ, J 1983b: Residues of chlorinated carbohydrates in fish and other components of aquatic medium in selected fishponds. Bulletin VÚRH Vodňany 19: 15-23

SVOBODOVÁ, Z, HRBKOVÁ, M, VOSTRADOVSKÝ, J 1983a: Chlorinated hydrocarbon residues in fish caught in the Lučina dam lake and in the drainage area of the Berounka river. Bulletin VÚRH Vodňany 19: 8-11

SVOBODOVÁ, Z, PIAČKA, V, VYKUSOVÁ, B, MÁCHOVÁ, J, HEJTMÁNEK, M, HRBKOVÁ, M, BASTL, J 1995: Residues of pollutants in Siluriformes from various localities of the Czech Republic. Acta Vet Brno 64: 195-208 
SVOBODOVÁ, Z, VYKUSOVÁ, B, MÁCHOVÁ, J, BASTL, J, HRBKOVÁ, M, SVOBODNÍK, J 1993a: Monitoring of foreign substances in fishes from the Jizera river in the Otradovice locality. Bulletin VÚRH Vodňany 29: 28-42

SVOBODOVÁ, Z, VYKUSOVÁ, B, MÁCHOVÁ, J, BASTL, J, HRBKOVÁ, M, SVOBODNÍK, J 1993b: Monitoring of foreign substances in fishes from the Elbe River in the sector between Ústí over Elbe and Hřensko. Bulletin VÚRH Vodňany 29: 79-99

SVOBODOVÁ, Z, VYKUSOVÁ, B, PIAČKA, V, HEJTMÁNEK, M, BASTL, J 1996: Checking the content of metals and of organic pollutants in tissues of marketable rainbow trout. Bulletin VÚRH Vodňany 32: 55-69

SVOBODOVÁ, Z, VYKUSOVÁ, B, PIAČKA, V, MÁCHOVÁ, J, BASTL, J, HRBKOVÁ, M, SVOBODNÍK, J 1994: Monitoring of foreign substances in fishes from the Elbe river in the Opatovice locality. Bulletin VÚRH Vodňany 30: 89-105

VÁCHA, F 1998: Information on Czech Republic fisheries. Eds. Hickley, P, Tompkins, H Fishing New Books, Blackwell Science, 48-57 pp.

VOSTRADOVSKÝ, J 2002: Den českého produkčního rybářství. Rybářství 40-41 pp.

YOU, L 2000: p,p' - DDE: an endocrine - active compound with the potential of multiple mechanisms of action. CIIT Activities 20: $1-8$

ŽLÁBEK, V, SVOBODOVÁ, Z, RANDÁK, T 2002: Comparison of the content of foreign substances in tissues of carp (Cyprinus carpio L.) and in bottom sediments of the Regent pond in 1992 and 2000. Bulletin VÚRH Vodňany 38: 3-15 